\title{
MULTI-HAZARD ASSESSMENT OF RC BRIDGES USING UNMANNED AERIAL VEHICLE-BASED MEASUREMENTS
}

\author{
ORKAN ÖZCAN ${ }^{1 *}$, OKAN ÖZCAN ${ }^{2}$ \\ ${ }^{1}$ Eurasia Institute of Earth Sciences, Istanbul Technical University, \\ Maslak, İstanbul, Turkey \\ ${ }^{2}$ Dept of Civil Engineering, Akdeniz University, Konyaaltı, Antalya, Turkey
}

Received 01 December 2017; accepted 29 May 2018

\begin{abstract}
The structural performance of reinforced concrete bridges is crucial regarding the bridge safety. Monitoring the bridge performance under multihazard effects such as scour, and earthquake becomes even more important. Thus, the scour depth along the piers and piles of bridge substructures has to be measured and tracked consistently in order for reliable multi-hazard bridge behaviour predictions. A practical Unmanned Aerial Vehicle based scour measurement method was proposed to increase the measurement accuracy and reduce the implementation costs. This method has been used in shallow and clear-water riverbeds. The Boğaçayı Bridge was selected as the case study located at the Boğaçayı River in Antalya, Turkey, since it was exposed to stream and flood, induced scour in the previous years. In the study region, the amount of scour was determined with considerable accuracy, and the scour measurements were used for generating the Three-Dimensional Finite Element model of the bridge. The multi-hazard performance of the bridge was acquired by implementing nonlinear static analysis using pushover curves corresponding to various scour depths concentrated at some of the bridge piers. Therefore, a continuously updateable multi-hazard bridge assessment system was proposed, which was implemented in bridges under scour and earthquake effects, regarding Unmanned Aerial Vehicle based measurements.
\end{abstract}

Keywords: bridge, earthquake, multi-hazard performance, scour monitoring, Unmanned Aerial Vehicle (UAV).

* Corresponding author. E-mail: ozcanork@itu.edu.tr

Copyright ( $(2) 2018$ The Author(s). Published by RTU Press

This is an Open Access article distributed under the terms of the Creative Commons Attribution License (http://creativecommons.org/licenses/by/4.0/), which permits unrestricted use,

distribution, and reproduction in any medium, provided the original author and source are credited. 
The scour observed in bridge substructures due to stream flow, or floods were found to be responsible for the premature failure of bridges under the multi-hazard environment (Boujia, Schmidt, Siegert, Van Bang, \& Chevalier, 2017; Dudunake, Huizinga, \& Fosness, 2017; Melville \& Coleman, 2000). Herein, the resultant scour depth around bridge piers and piles has been measured with reasonable accuracy (Pandey, Sharma, Ahmad, \& Karna, 2018) in order for reliable performance evaluation of the bridges under severe ground motions. As shown in previous studies, sonar (Fisher, Chowdhury, Khan, \& Atamturktur, 2013; Topczewski, Cieśla, Mikołajewski, Adamski, \& Markowski, 2016; Zheng, Xu, Cheng, Wang, \& Lu, 2018), ground-penetrating radar (Burrell, Gurrola, \& Mickus, 2008), radio frequency identification (Chapuis, Dufour, Provansal, Couvert, \& De Linares, 2015), and accelerometer (Bao, Swartz, Vitton, Sun, Zhang, \& Liu, 2017; Prendergast, Hester, Gavin, \& O'sullivan, 2013) based measurement systems were frequently implemented for field scour measurements. Despite the primitive Unmanned Aerial Vehicle (UAV)-based research technologies, which embodied river bathymetry modelling (Flener, 2013), risk assessment and flood analysis (Hackl, Adey, Woźniak, \& Schümperlin, 2017; Jaud, Grasso, Le Dantec, Verney, Delacourt, Ammann, ... \& Grandjean, 2016; Tamminga, Eaton, \& Hugenholtz, 2015), other traditional methods were often used for scour measurements. Besides, as mentioned in previous researches, similar correlation was obtained between the bathymetric data acquired from high-resolution images in shallow water and the real values that were obtained from field surveys. In order to evaluate the multi-hazard performance of reinforced concrete (RC) bridges under scour and earthquake effects, a limited number of studies, which investigated the bridge performance from the probabilistic point of view regarding seismic fragility analyses (Alipour \& Shafei, 2012; Avşar, Atak, \& Caner, 2017; Ganesh Prasad \& Banerjee, 2013), were conducted. Herein, it was demonstrated that the lateral capacity and the shear demand of the investigated bridges tended to deteriorate with the increase in scour depth. In addition, the performance of scoured bridge piers under flood-induced loads was scrutinized (Akib, Fayyadh, \& Othman, 2011; Hung \& Yau, 2014, 2017; Kızılduman, Yanmaz, \& Caner, 2017; Lin, Bennett, Han, \& Parsons, 2012; Tanasić \& Hajdin 2018) and a significant degradation was monitored in the lateral stiffness and strength of the bridge piers while inducing augmented failure possibilities. The inferior behaviour of scour-damaged bridges was established under lateral seismic loads (Song, Wang, \& Huang, 2015) and by using pushover curves (Klinga \& Alipour, 2015) in which the lateral 
seismic resistance was determined to reduce with increasing scour. All of the works above utilized equal amount of scouring in all bridge piers and neglected the effect of scouring that was concentrated at some of the bridge piers. Actually, for many river crossing bridges, only some of the piers that were located at the river are under concentrated scouring without influencing the other piers.

\section{Motivation}

In this study, the effect of scouring, which was concentrated only at some of the bridge piers, was investigated by UAV based high-resolution scour monitoring system for clear water and shallow water riverbeds. At this moment, regarding installation costs, ease of implementation and economy, none of those above monitoring techniques was able to capture the scour depths for clear and shallow water riverbed in a practical manner. Thus, a UAV based scour monitoring method was proposed for continuous and reliable tracking of bridge performance using evaluating the condition of the substructure system that includes the piers and the abutments with supporting piles.

In order for reliable bridge multi-hazard tracking, nonlinear static analysis (pushover analysis) methods were implemented in the light of the guidelines ATC-40 (Applied Technology Council, 1996), FEMA-356 (Council B.S.S., 2000), and FEMA-440 (Federal Emergency Management Agency, 2005). The proposed bridge multi-hazard tracking system was applied to the Boğaçayı Bridge that is located in Antalya, Turkey as a case study. Regarding the guidelines, the performance points have been obtained for various scour depths considering the seismicity of the study region as per Turkish Earthquake Code (TEC, 2007). Therefore, the performance of the bridges, which were exposed to the multi-hazard environment including scouring along with the earthquake, was attained reliably and practically.

\section{Methodology}

\subsection{Proposed Scour Monitoring Technique}

The proposed methodology for high-resolution scour monitoring the constituted three-dimensional point cloud generation process by implementing UAV derived aerial photos. Herein, the Structure-fromMotion (SfM) technique was used instead of high-resolution traditional topographical survey methods. The model of three-dimensional (3D) 
structures such as terrain, buildings, and landforms were obtained by using motion-integrated two-dimensional (2D) image clusters. In SfM technique, model geometry, camera position, and orientation data were automatically acquired with a simultaneous solution. The object features such as edges and corners that were remotely sensed were tracked from one to other imagery to determine the relationship between the imageries. The feature trajectories, which implied the route that the objects follow, were used to designate the 3D location of the object and the camera motion (Javernick, Brasington, \& Caruso, 2014). High measurement accuracies were acquired for the regions with different geomorphic properties that implemented the SfM technique along with UAV derived imageries (Castillo, Pérez, James, Quinton, Taguas, \& Gómez, 2012; Hackl, Adey, Woźniak, \& Schümperlin, 2017; James \& Robson, 2012; Javernick, Brasington, \& Caruso, 2014). At this moment, the digital surface model (DSM) of the river basin, which included the bridge and consequent scour depths along bridge piers, was determined by UAV and were compared to manual measurements taken at piers. The 3D surfaces at the river regions, which included the bridge, were obtained with high accuracy using 85\% overlapping ratio between aerial photos and ground sampling distance (GSD) of 1-2 cm/pixel. Thus, acquired high-resolution orthophotos and dense point clouds measured the scour depths around bridge piers. The scour depths monitored at the bridge piers were considered as input data in bridge substructure modelling.

\subsection{Bridge modelling}

The bridge 3 dimensional finite-element model (3D-FEM) was generated using SAP2000 software incorporating substructure components such as RC piles and pile caps. Considering the soil conditions at the river basin on which the bridge was constructed, soil layer properties were used to model the soil surrounding the bridge piles. The soil layers surrounding the bridge piles were modelled by lateral and vertical nonlinear springs attached to the piles at several heights using $p-y$ and $t-z$ curves, respectively. The curve characteristics were designated according to the soil layer type and its relative height to the ground surface. Herein, different soil models were implemented considering sand (Reese, Cox, \& Koop, 1974; Wang \& Reese, 1993) and limestone (McVay \& Niraula, 2004; Niraula, 2004) layers. In modelling of piles, each of the soil layers existing along the pile length was divided into several segments in order for reliable determination of soil spring properties along with the soil depth. Thus, the nonlinear soil spring properties were assumed constant along the constituted soil segments. For layered soil deposits, the characteristics of a nonlinear soil spring at a specified depth along the pile were designated accordingly relative to 
the ground surface. The resistance provided by the $p-y$ and $t-z$ curves was assigned to the pile segments after multiplying the obtained spring capacities by the length of the pile segment and by the surface area of the pile segment under consideration, respectively. The same process was applied to the bridge piers that were embedded wholly or partially into the soil.

Rigid beam elements were used for the pile caps that ensured the connection between piers and piles. With this regard, the pile cap was decomposed into the rigid pier and pile segments having equal heights that were defined under the mid-height of the pile cap. Thus, for the regions, which characterized the pier connections to the pile cap, the soil spring properties were assigned by the pier properties. Similarly, for the remaining regions, which mimic pile connections to the pile cap, pile properties were considered while defining the soil properties. The characteristics of the nonlinear soil springs were redefined about the scoured ground surface to reflect the influence of scouring in the structural model. Considering the developing resistance of the soil springs with the depth below the ground surface, the capacity of the surrounding soil layers tended to deteriorate with increasing scour depth for a specific depth along the bridge pile.

Further, the adverse effect of frequently aligned piles and piers on lateral resistance of pile groups was captured via $p$-multipliers that signified the deterioration of lateral soil resistance considering the shadowing effect in pile groups. Herein, the p components, which defined the lateral resistance for $p-y$ curves, were multiplied by $p$-multipliers that were defined as $0.70,0.50$ and 0.35 for leading, second and remaining pile rows, respectively (AASHTO LRFD, 2014). In order for completeness and consistency, an identical process was conducted for soil-embedded piers in an appropriate direction compatible with the pushover analyses.

The pier caps and the simply supported girders were modelled with beam elements. All girders and the RC slab of the bridge were modelled as one beam element having the identical properties with the superstructure regarding weight, mass and cross section. In the longitudinal direction, the elastomeric bearings located at the girder supports were idealized as link elements that provided the shear stiffness. Besides, the gap elements were defined that represented the spacing between two consecutive girders. After closing of the gap, infinite stiffness occurred due to the pounding of girders. Since the presence of the RC shear keys prevented the lateral movements of the girders, links were deleted in the transverse direction. Plastic hinges were defined at the critical regions of piles, piers, and abutments at which the maximum bending moments occurred. Plastic hinge 

bilinearized and were directly implemented in plastic hinge definitions. Top and bottom regions of piers and abutments were specified as the potential plastic hinge regions at where the maximum bending moment was expected to occur. For piles, the connection between the pile cap and the pile was determined as one of the plastic hinge regions. The location of possible hinges, which were expected to occur along the pile, was determined by continuous tracking of the maximum bending moment region along the pile length. Regarding the random deployment of soil layers and concentration of scouring at the piers at which the river surface runoff was maximal, the probable plastic hinge locations were tracked by performing successive pushover analyses. Thus, the migration of the plastic hinge was followed and the most probable hinging location with maximum bending moment along the pile was determined. During the pushover analyses, the effective stiffness was taken as half of the gross stiffness for all members other than the prestressed concrete (PC) girders (AASHTO LRFD, 2014).

\subsection{Case study - Boğaçayı Bridge}

For the case study, the Boğaçayı Bridge, which was located at the Boğaçayı River in Antalya Province, Turkey was selected since this bridge was exposed to flood and stream induced scour in the recent years. At this moment, only the middle bridge piers were exposed to significant scouring along with the river basin, since the river stream was concentrated at the middle piers by the majority. The generated SfM point clouds and top view elevation model from ultra-high-resolution UAV imagery along the bridge were used to acquire the scour depths at the bridge piles (Figure 1). The amount of scouring at the piers was detected by the longitudinal and transverse cross-sections taken along the bridge. As regard to the study region considering maximum, average and minimum elevation data, a maximum of $2.20 \mathrm{~m}$ of scouring was monitored at the middle piers (Figure 2). Additional scour depths of $3.70 \mathrm{~m}, 4.95 \mathrm{~m}, 6.20 \mathrm{~m}$ and $7.45 \mathrm{~m}$ were considered that were concentrated at the mid piers to provide future performance predictions for the bridge under severe scouring.

The investigated bridge had twelve piers that were equispaced at $20.30 \mathrm{~m}$ spans and two abutments located at $20.60 \mathrm{~m}$ from the last piers at both ends of the bridge. At each singly supported span, eight PC girders, that were laterally equispaced at $1.70 \mathrm{~m}$ and $22 \mathrm{~cm}$ thick RC slab, constituted the bridge superstructure. The gap between two consecutive girders in the longitudinal direction was 


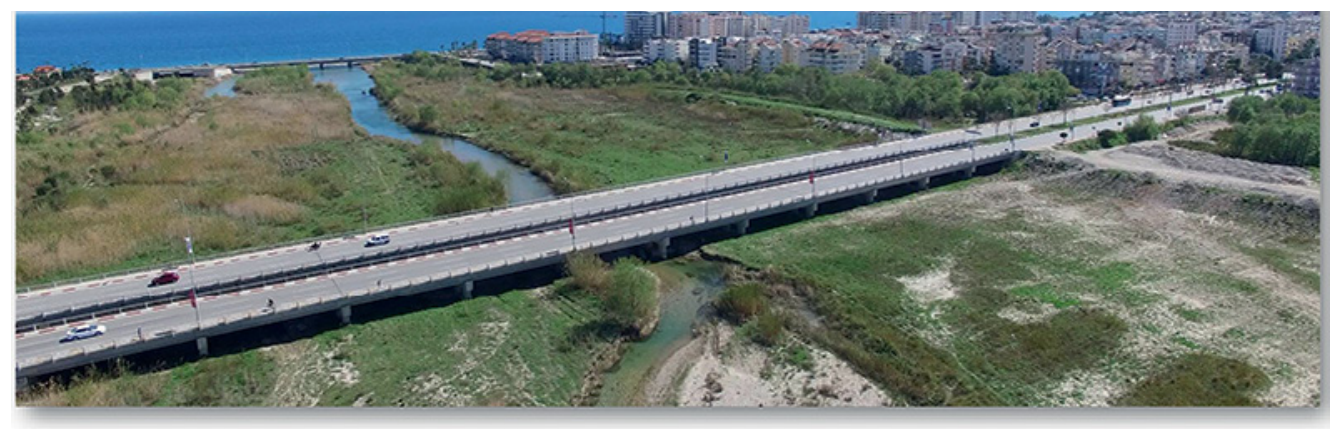

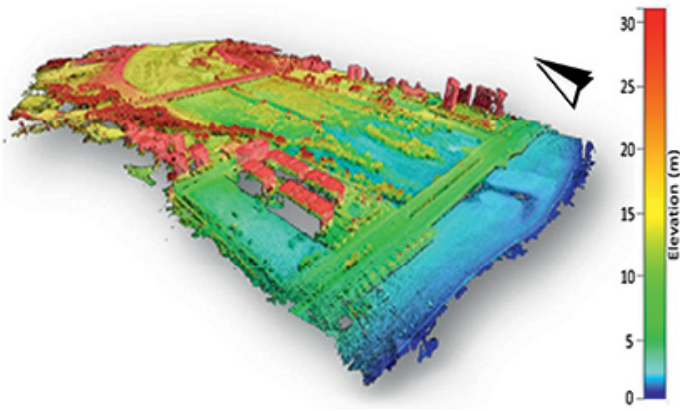

UAV-derived 3D point cloud

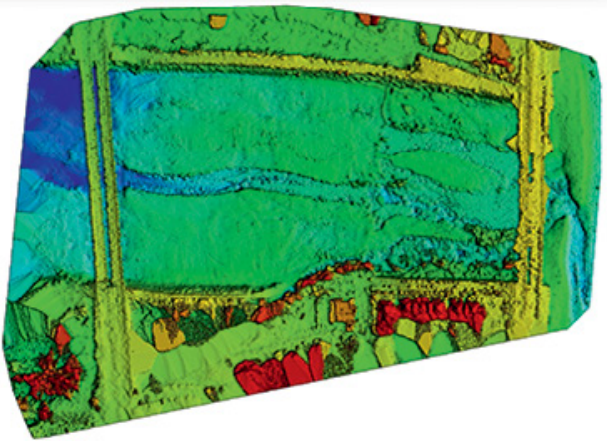

Top view elevation model

Figure 1. Case study region

a) longitudinal direction

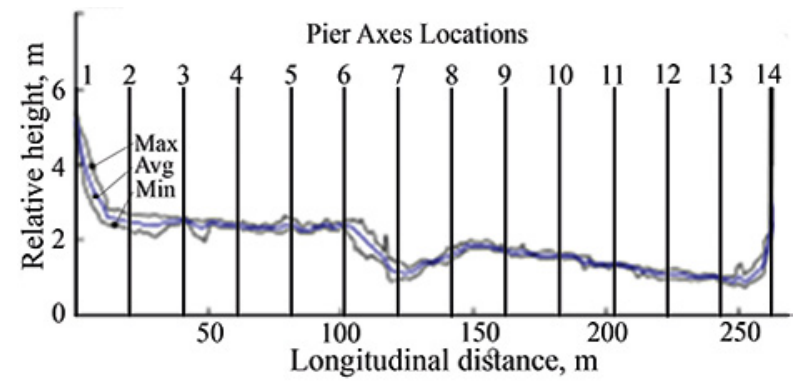
direction b) transverse

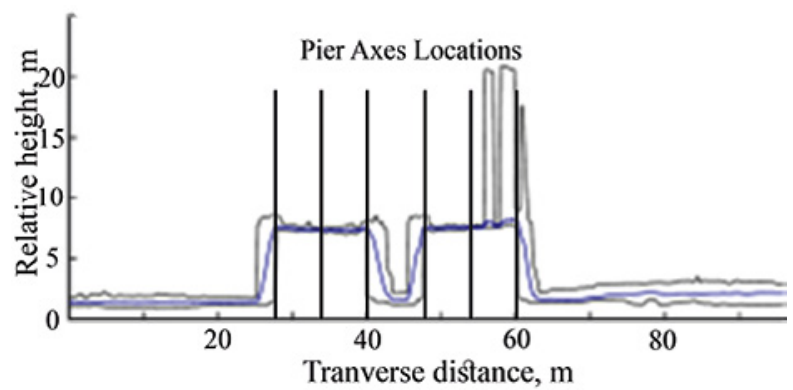

Figure 2. Cross sections acquired from dense point cloud 


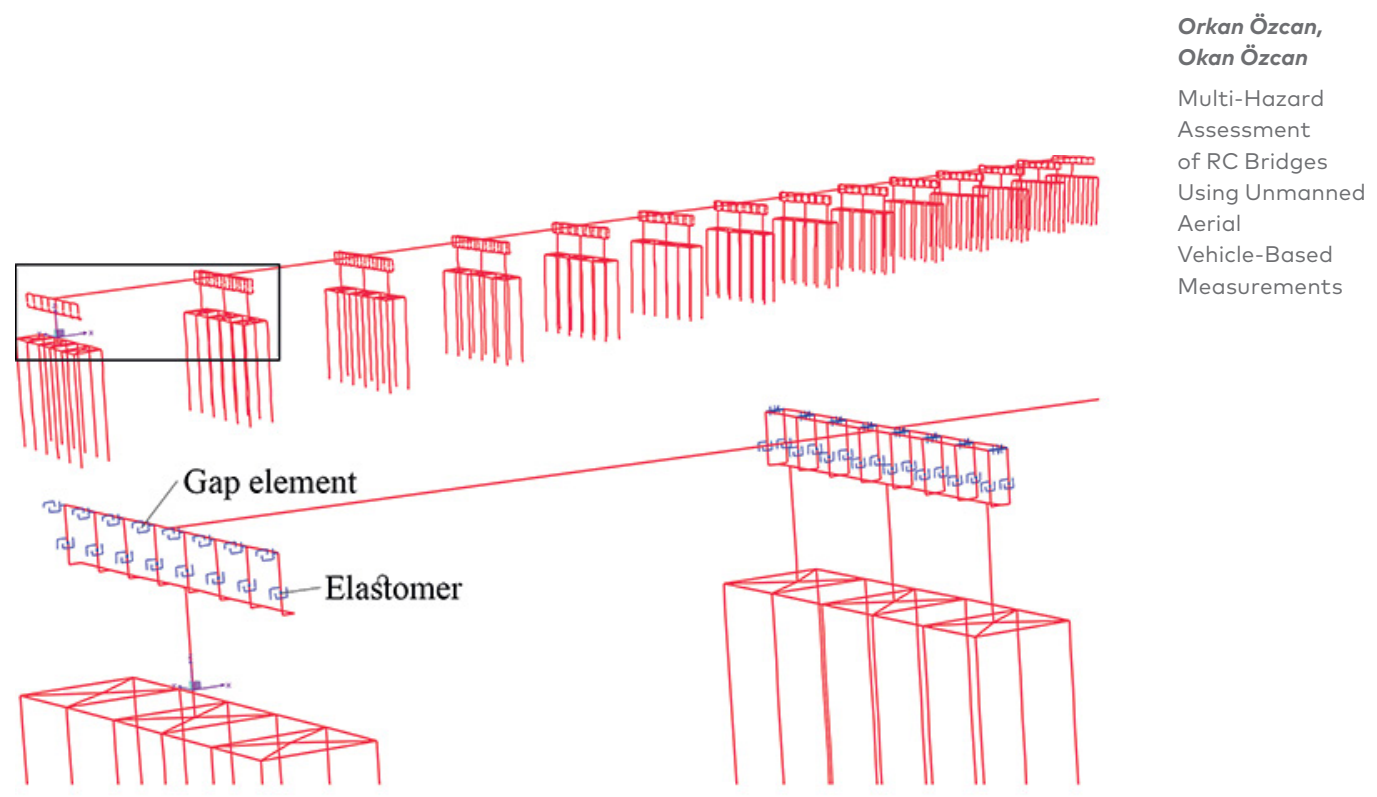

Figure 3. Three-dimensional finite element method of the investigated bridge and modelling details

identified as approximately $50 \mathrm{~mm}$ during bridge field inspection. The 60 -durometer elastomeric bearings were placed at each end of the singly supported PC girders with dimensions of $25.00 \times 45.00 \times 9.50 \mathrm{~cm}$ (width $\times$ depth $\times$ height). Thus, the shear modulus and consequent effective stiffness of the elastomer was taken as $1.38 \mathrm{MPa}$ and $1634.20 \mathrm{~N} / \mathrm{mm}$, respectively (Figure 3).

As shown in the bridge 3D-FEM (Figure 3), at each pier, three $4.50 \mathrm{~m}$ long pier columns $(1.00 \times 2.00 \mathrm{~m})$ were connected to the pier cap $(1.20 \times 1.10 \mathrm{~m})$ and were oriented in a way that the weak bending axis of the columns coincided with the bridge transverse axis. The pier columns were reinforced with 40 deformed rebars of $26 \mathrm{~mm}$ diameter and transversely reinforced with $10 \mathrm{~mm}$ diameter interlocking ties with a spacing of $100 \mathrm{~mm}$. The spacing between the three pier columns were $5.25 \mathrm{~m}$ in the transverse direction. The abutments had cross-section dimensions of $1.20 \times 14 \mathrm{~m}$, longitudinal reinforcement of 192 deformed bars of $16 \mathrm{~mm}$ diameter and $10 \mathrm{~mm}$ diameter transverse bars spaced at $100 \mathrm{~mm}$. At the bottom of each pier and abutment, a pile cap with dimensions of $3.00 \times 14.00 \times 1.50 \mathrm{~m}$ was provided to connect ten piles of $1 \mathrm{~m}$ diameter and $12 \mathrm{~m}$ long. The RC piles were spaced at $2.70 \mathrm{~m}$ and $3.00 \mathrm{~m}$ in longitudinal and transverse directions, respectively. All the piles were identically reinforced with 16 rebars with a $26 \mathrm{~mm}$ diameter and $10 \mathrm{~mm}$ diameter spirals with $100 \mathrm{~mm}$ pitch. Since the net spacing of piles and piers was lower than three pile diameters, group effect 
was considered in calculations as per AASHTO LFRD (2014) bridge regulations.

The soil layer conditions were clarified by the geotechnical data presented in project drawings, and it was revealed that an almost homogeneous soil layer decomposition existed in the study region. Herein, the sand layers were located at different heights above the pile cap elevation. The following soil layers comprised approximately $5.00 \mathrm{~m}$ limestone underlain by sand. For a reliable structural model generation, the topmost sand layer and each of the following limestone and sand layers were divided into two and five sub layers, respectively. The properties of $p-y$ and $t-z$ curves were defined concerning the mid-elevation of the sub-layers. The properties of nonlinear soil springs for top and bottom half of the pile cap were determined according to the pier and pile properties, respectively. In modelling, since the $p-y$ curves were generated in both longitudinal and transverse directions for the abutments, the influence of passive or active earth pressures was ignored. The plastic hinges were defined for RC members at their most probable locations to perform nonlinear static analysis using pushover analysis in both directions. For piers and abutments, top and bottom regions were identified as the critical regions. However, for piles, the first hinge location was defined as the maximum elevation of the pile and the location of the second hinge was tracked by performing successive pushover analyses. The moment and plastic curvature capacities of the RC piers, piles and abutments were calculated via standard section analysis using considering 11, 7 and 1 axial load levels defined in both directions, respectively. The plastic hinge lengths were considered equal to the depth of the cross-sections.

\section{Results and Discussion}

The scour depths at the substructure system of the investigated bridge were measured by the transverse and longitudinal cross sections taken along the bridge piers by the proposed UAV based measurement method. As the maximum, $2.20 \mathrm{~m}$ of scour depth was measured at the mid piers. Regarding the scour measurements as an input for the pushover analyses, the nonlinear static analyses were conducted as coupled with modal analyses considering six different scour depths that were concentrated at mid piers. The performance points were evaluated regarding four methods as described in the guidelines of ATC-40 (Applied Technology Council, 1996), FEMA-356 (Council B.S.S., 2000), and FEMA-440 (Federal Emergency 

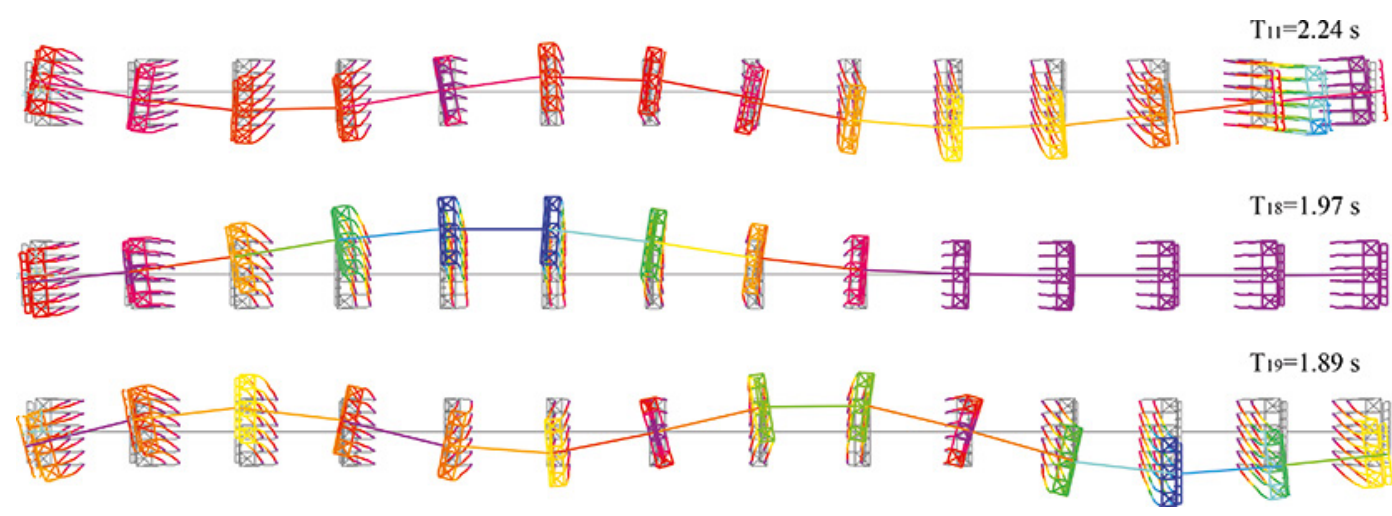

Figure 4. Modal properties with the maximum mass participation (top view)

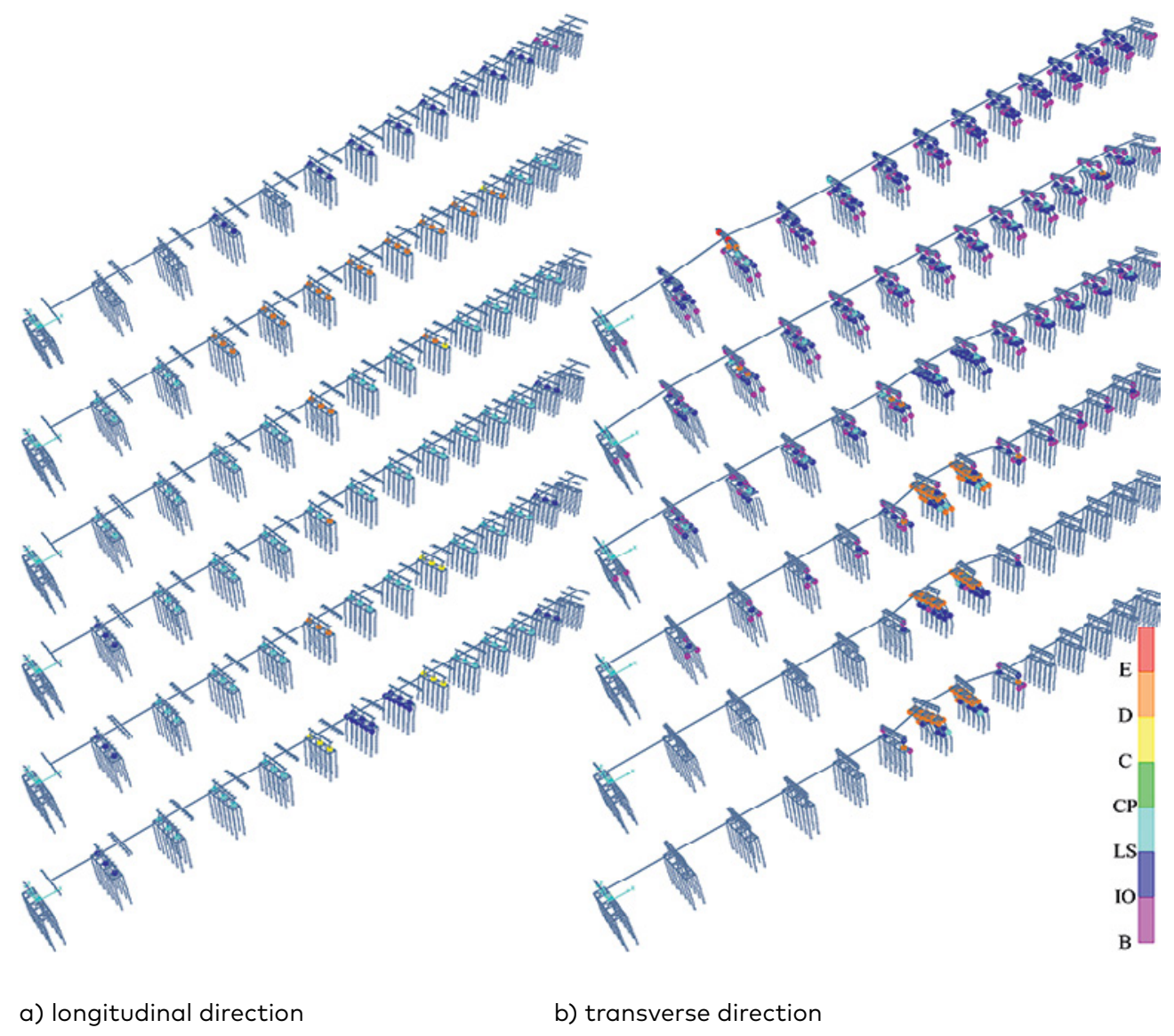

Figure 5. Plastic hinges locations at failure for scouring depths 
Management Agency, 2005) (for Equivalent Linearization method FEMA-440EL and Displacement Modification method - FEMA-440DM). In the performance point evaluation, the design spectrum, which was compatible with the study region as per Turkish Earthquake Code (TEC, 2007) was implemented (seismic zone 2 and local site class $\mathrm{Z} 4$ ). For the analysed bridge, in the calculations, effective ground acceleration of $0.3 \mathrm{~g}$ and the characteristic periods of $0.2 \mathrm{~s}$ and $0.9 \mathrm{~s}$ were used. The first three modal shapes (Figure 4), which had the maximum modal mass participation and corresponding natural vibration periods, were insignificantly affected by the scouring since only two of the bridge piers were exposed to severe scouring. The first reason underneath this phenomenon was the scour being concentrated only at the middle piers. Figures 5 and 6 demonstrated the results of the pushover analyses performed in longitudinal and in transverse directions. In Figures $5 \mathrm{a}$ and $5 \mathrm{~b}$, the first and the last bridge failure schemes, which represent the plastic hinge locations at failure, indicates the condition without scouring and the maximum scours at the mid piers, respectively. The limit states for the developed plastic hinges at pier columns and piles are demonstrated accordingly (Immediate Occupancy (IO), Life Safety $(L S)$, and Collapse Prevention $(C P)$ ) for immediate occupancy, life safety and collapse prevention, respectively). As regard to the pushover curves and the performance points obtained in the longitudinal direction, the bridge lateral capacity regarding load and displacement remained almost constant irrespective of the scour amount (Figure 6a). Herein, the pushover curves obtained in the longitudinal direction were almost identical. Similarly, the corresponding performance points at each scour level were observed to be approximately constant (approximately $0.055,0.070$ and 0.080 for ATC-40 (Applied Technology Council, 1996), FEMA-356 (Council B.S.S., 2000), and FEMA-440DM (Federal Emergency Management Agency, 2005), respectively). The results obtained from ATC-40 (Applied Technology Council, 1996), and FEMA-356EL (Council B.S.S., 2000) were identical in the analyses and FEMA-440DM (Federal Emergency Management Agency, 2005) did not converge to a solution for scouring depths above $4.00 \mathrm{~m}$.

Besides, as demonstrated by the failure mechanisms, the formation of plastic hinges commenced at the piers having the maximum scour depth and advanced by spreading to the adjacent piers. The plastic hinges occurred only at the bottom of the pier columns while localizing the plastic rotations only at these regions and remaining the top of the columns and piers undamaged. Since the plastic hinges developed at the bottom of the piers rather than at the piles due to the superior capacity of the pile group over that of piers in the 
analysed direction, the changes in scour depths were monitored to have a trivial effect on the performance in the longitudinal direction within the range of scour depths under investigation. In addition, middle pier, which stayed at an almost constant level irrespective of the scour depth, verified this behaviour (Figure 7). The formation of plastic hinges at the top of piles, which were located at the middle piers, was observed only for the case at which the scour depth was the maximum.

However, in the transverse direction (Figure 5b), the failure initiated with a plastic hinge at the top of the pile at which the maximum scour depth was measured. For the case, which represented the condition without scouring, the plastic hinges were monitored to spread over almost all adjacent piers. As the scour depth, which concentrated at the middle piers increased, the initial plastic hinge
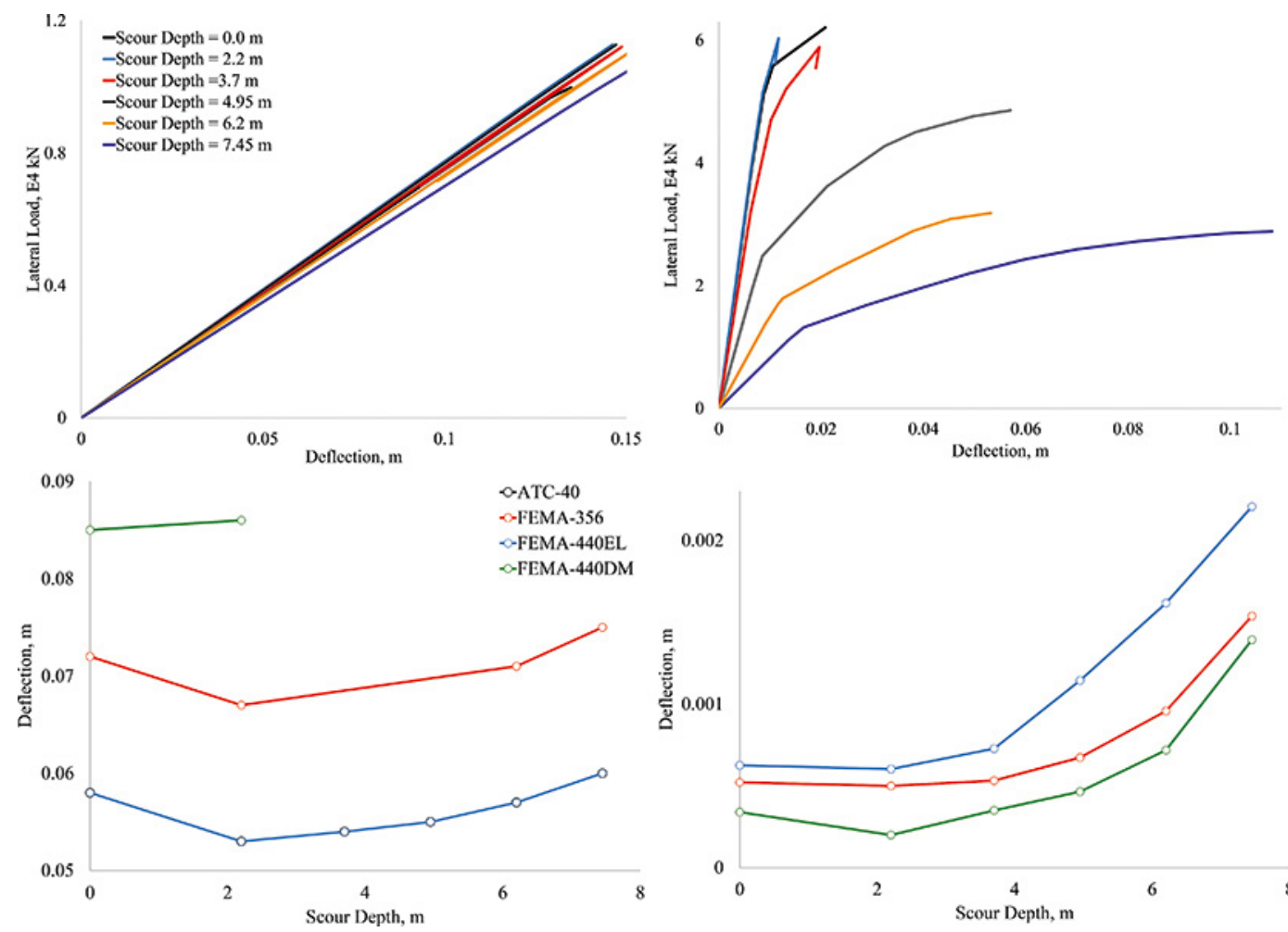

a) longitudinal direction

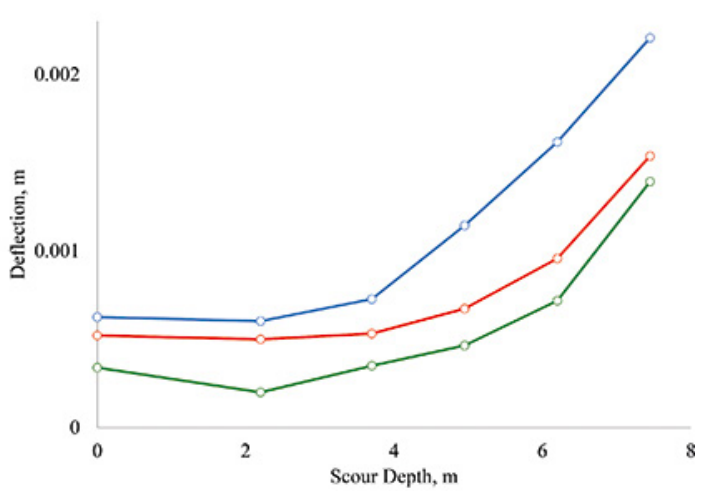

b) transverse direction

Figure 6. Pushover curves and performance points for scouring depths 


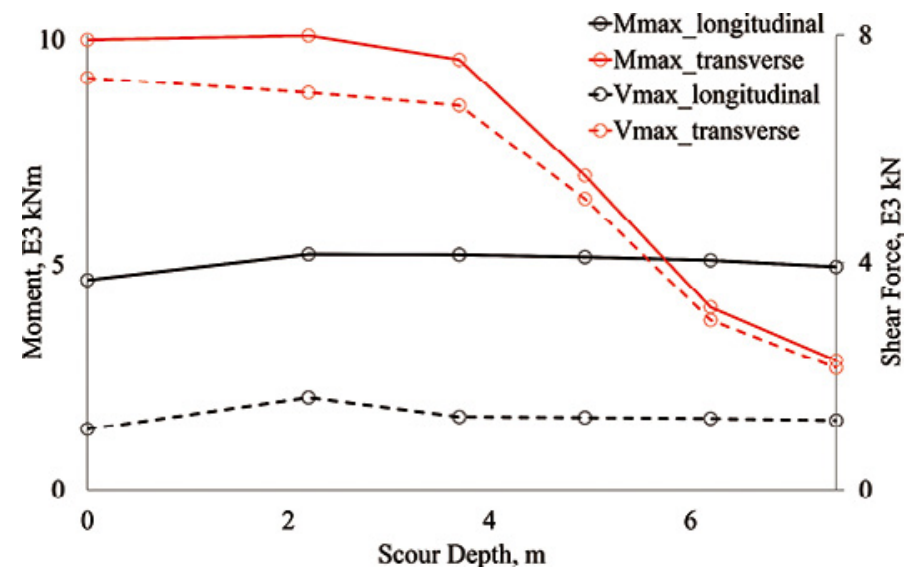

Figure 7. The variation of the maximum internal forces with scouring depth

was determined to form the bridge piles having the maximal scour depth and second plastic hinges formed at the piles instead of spreading to the adjacent piles. The spreading of plastic hinges over the adjacent piers tended to decrease with increasing amount of scour. As shown in Figure 6b, the stiffness and the strength tended to decrease by the scour depth while augmenting displacement ductility. Regarding the performance points corresponding to each scours depth, the deflections were observed to increase abruptly approximately after a scour depth of $4.00 \mathrm{~m}$. Since the lateral strength of the bridge in a transverse direction substantially exceeds the strength in the longitudinal direction, the performance points were monitored to decrease. Thus, the bridge will survive from a probable earthquake with much lower damage in the transverse direction than in the longitudinal direction.

Besides, the plastic hinges at the piles were in the tendency to concentrate only in the pile groups by increasing the moments at the piles and consequently by forming an additional hinge along the pile rather than spreading to the adjacent piers. Thus, the bending moments and corresponding shear force at the bottom of the middle pier column were monitored to diminish by increasing scour depth (Figure 7). The internal forces tended to diminish after a scour depth of approximately $4.00 \mathrm{~m}$. As the scour depth amplified at the mid piers, the bridge lateral load capacity deteriorated while enhancing lateral displacement capacity since the plastic hinge spreading was impounded only in the pile group by forming additional pile hinges rather than spreading to the adjacent piers. 


\section{Conclusions}

The stream or flood-induced scouring was designated to be responsible for the premature failure of most bridges built on riverbeds. Thus, the scour measurements along the bridge substructure systems were conducted in an effective, continuous, practical and economical way. Herein, a Structure-from-Motion integrated Unmanned Aerial Vehicle based scour monitoring system was proposed to provide high-resolution scour measurements at bridge substructures. The amount of scouring at bridge piers was considered as the input data for the multi-hazard performance evaluation of the Boğaçayı Bridge in Antalya, Turkey that was selected as the case study. For the modelling of the investigated bridge, the soil layers were regarded as lateral and vertical nonlinear springs located at various heights along the bridge piles. The pile group effect was modelled using p-multipliers in both directions for both piers and piles. The investigated bridge had twelve piers between which eight prestressed concrete girders were laterally equispaced at $1.70 \mathrm{~m} .25 .00 \times 45.00 \times 9.50 \mathrm{~cm}$ (width $\times$ depth $\times$ height) elastomeric bearings supported prestressed concrete girders with a shear modulus and effective stiffness of $1.38 \mathrm{MPa}$ and $1634.20 \mathrm{~N} / \mathrm{mm}$, respectively. Six different scour depths concentrated only on the mid piers was observed to have a negligible influence on the modal characteristics and the lateral performance in the longitudinal direction regarding lateral stiffness and strength. The modal shapes and the corresponding periods were observed to remain constant (approximately 0.055, 0.070 and 0.080 for ATC-40 (Applied Technology Council, 1996), FEMA-356 (Council B.S.S., 2000), and FEMA-440DM (Federal Emergency Management Agency, 2005), respectively) with increasing scour depth. In addition, the change in lateral strength and stiffness was not monitored to exceed 3\% in the longitudinal direction. Similarly, the performance points remained approximately constant regarding each guideline while showing indistinct variation with scouring depth. Herein, since the lateral capacity of the piers were lower than that of the pile group in the longitudinal direction, the formation of plastic hinges commenced at the bridge piers. Thus, the bridge performance was not affected by scouring. However, in the transverse direction, since the failure mechanism was altered due to the initiation of plastic hinging in piles rather than in piers and the spreading of plastic hinging to adjacent piers was prevented, the deterioration in lateral load capacity and enhancement in ductility was monitored with the increase in scour depth. Regarding the performance points corresponding to each scours depth, the deflections were observed to increase abruptly approximately after a scour depth of $4.00 \mathrm{~m}$. Consequently, the applicability and the robustness of the proposed method was verified by a bridge case study located at a multi-hazard environment including both scouring and earthquake. 


\section{Acknowledgements}

This work was supported by the Akdeniz University Scientific Research Project (AU-BAP). Project No: FBA-2018-2877.

\section{REFERENCES}

AASHTO LRFD (2014). AASHTO LRFD bridge design specifications. Transportation (Amst). American Association of State Highway and Transportation Officials, Inc.: Washington, $D C$.

Akib, S., Fayyadh, M. M., \& Othman, I. (2011). Structural behaviour of a skewed integral bridge affected by different parameters. Balt J Road Bridge Eng, 6(2), 107-114. https://doi.org/10.3846/bjrbe.2011.15

Alipour, A., \& Shafei, B. (2012). Performance assessment of highway bridges under earthquake and scour effects. In Proceedings of the 15th world conference on earthquake engineering (pp. 24-28).

Applied Technology Council. (1996). Seismic evaluation and retrofit of concrete buildings. 2. Appendices. ATC.

Avşar, Ö., Atak, B., \& Caner, A. (2017). In-depth investigation of seismic vulnerability of an aging river bridge exposed to scour. Journal of Performance of Constructed Facilities, 31(5), 04017044. https://doi.org/10.1061/(ASCE)CF.1943-5509.0001036

Bao, T., Swartz, R. A., Vitton, S., Sun, Y., Zhang, C., \& Liu, Z. (2017). Critical insights for advanced bridge scour detection using the natural frequency. Journal of Sound and Vibration, 386, 116-133. https://doi.org/10.1016/j.jsv.2016.06.039

Boujia, N., Schmidt, F., Siegert, D., Van Bang, D. P., \& Chevalier, C. (2017). Modelling of a bridge pier subjected to scour. Procedia engineering, 199, 2925-2930. https://doi.org/10.1016/j.proeng.2017.09.343

Burrell, J., Gurrola, H., \& Mickus, K. (2008). Frequency domain electromagnetic and ground penetrating radar investigation of ephemeral streams: case study near the Southern High Plains, Texas. Environmental Geology, 55(6), 1169. https://doi.org/10.1007/s00254-007-1063-5

Castillo, C., Pérez, R., James, M. R., Quinton, J. N., Taguas, E. V., \& Gómez, J. A. (2012). Comparing the accuracy of several field methods for measuring gully erosion. Soil Science Society of America Journal, 76(4), 1319-1332. https://doi.org/10.2136/sssaj2011.0390

Chapuis, M., Dufour, S., Provansal, M., Couvert, B., \& De Linares, M. (2015). Coupling channel evolution monitoring and RFID tracking in a large, wandering, gravel-bed river: Insights into sediment routing on geomorphic continuity through a riffle-pool sequence. Geomorphology, 231, 258-269. https://doi.org/10.1016/j.geomorph.2014.12.013

Council B. S. S. (2000). Prestandard and commentary for the seismic rehabilitation of buildings. Report FEMA-356, Washington, DC.

Dudunake, T. J., Huizinga, R. J., \& Fosness, R. L. (2017). Bridge scour countermeasure assessments at select bridges in the United States, 2014-16 (No. 2017-1048). US Geological Survey. https://doi.org/10.3133/ofr20171048 
Federal Emergency Management Agency. (2005). Improvement of nonlinear static seismic analysis procedures. FEMA 440, prepared by Applied Technology Council (ATC-55 Project).

Fisher, M., Chowdhury, M. N., Khan, A. A., \& Atamturktur, S. (2013). An evaluation of scour measurement devices. Flow Measurement and Instrumentation, 33, 55-67. https://doi.org/10.1016/j.flowmeasinst.2013.05.001

Flener, C. (2013). Calibrating Deep Water Radiance in Shallow Water: Adapting Optical Bathymetry Modeling to Shallow River Environments, Boreal Environment Research 18: 488-501.

Ganesh Prasad, G., \& Banerjee, S. (2013). The impact of flood-induced scour on seismic fragility characteristics of bridges. Journal of Earthquake Engineering, 17(6), 803-828. https://doi.org/10.1080/13632469.2013.771593

Hackl, J., Adey, B. T., Woźniak, M., \& Schümperlin, O. (2017). Use of Unmanned Aerial Vehicle Photogrammetry to Obtain Topographical Information to Improve Bridge Risk Assessment. Journal of Infrastructure Systems, 24(1), 04017041. https://doi.org/10.1061/(ASCE)IS.1943-555X.0000393

Hung, C. C., \& Yau, W. G. (2014). Behavior of scoured bridge piers subjected to flood-induced loads. Engineering Structures, 80, 241-250. https://doi.org/10.1016/j.engstruct.2014.09.009

Hung, C. C., \& Yau, W. G. (2017). Vulnerability evaluation of scoured bridges under floods. Engineering Structures, 132, 288-299. https://doi.org/10.1016/j.engstruct.2016.11.044

James, M. R., \& Robson, S. (2012). Straightforward reconstruction of 3D surfaces and topography with a camera: Accuracy and geoscience application. Journal of Geophysical Research: Earth Surface, 117(F3). https://doi.org/10.1029/2011JF002289

Jaud, M., Grasso, F., Le Dantec, N., Verney, R., Delacourt, C., Ammann, J., ... \& Grandjean, P. (2016). Potential of UAVs for monitoring mudflat morphodynamics (application to the seine estuary, France). ISPRS International Journal of Geo-Information, 5(4), 50. https://doi.org/10.3390/ijgi5040050

Javernick, L., Brasington, J., \& Caruso, B. (2014). Modeling the topography of shallow braided rivers using Structure-from-Motion photogrammetry. Geomorphology, 213, 166-182. https://doi.org/10.1016/j.geomorph.2014.01.006

Kızılduman, H. S., Yanmaz, A. M., \& Caner, A. (2017). Stability of bridge piers subjected to a probable flood event followed by a probable seismic event. Journal of performance of constructed facilities, 32(1), 04017120. https://doi.org/10.1061/(ASCE)CF.1943-5509.0001123

Klinga, J. V., \& Alipour, A. (2015). Assessment of structural integrity of bridges under extreme scour conditions. Engineering Structures, 82, 55-71. https://doi.org/10.1016/j.engstruct.2014.07.021

Lin, C., Bennett, C., Han, J., \& Parsons, R. L. (2012). Integrated analysis of the performance of pile-supported bridges under scoured conditions. Engineering structures, 36, 27-38. https://doi.org/10.1016/j.engstruct.2011.11.015

McVay, M. C., \& Niraula, L. (2004). Development of PY curves for large diameter piles/drilled shafts in limestone for FBPIER (No. Final Report,).

Melville, B. W., \& Coleman, S. E. (2000). Bridge scour. Water Resources Publication. 
Niraula, L. D. (2004). Development of Modified Tz Curves for Large Diameter Piles/ drilled Shafts in Limestone for Fb-pier (Doctoral dissertation, University of Florida).

Pandey, M., Sharma, P. K., Ahmad, Z., \& Karna, N. (2018). Maximum scour depth around bridge pier in gravel bed streams. Natural Hazards, 91(2), 819-836. https://doi.org/10.1007/s11069-017-3157-z

Prendergast, L. J., Hester, D., Gavin, K., \& O'sullivan, J. J. (2013). An investigation of the changes in the natural frequency of a pile affected by scour. Journal of Sound and Vibration, 332(25), 6685-6702. https://doi.org/10.1016/j.jsv.2013.08.020

Reese, L. C., Cox, W. R., \& Koop, F. D. (1974). Analysis of laterally loaded piles in sand. Offshore Technology in Civil Engineering Hall of Fame Papers from the Early Years, 95-105.

Song, S. T., Wang, C. Y., \& Huang, W. H. (2015). Earthquake damage potential and critical scour depth of bridges exposed to flood and seismic hazards under lateral seismic loads. Earthquake Engineering and Engineering Vibration, 14(4), 579-594. https://doi.org/10.1007/s11803-015-0047-9

Tamminga, A. D., Eaton, B. C., \& Hugenholtz, C. H. (2015). UAS-based remote sensing of fluvial change following an extreme flood event. Earth Surface Processes and Landforms, 40(11), 1464-1476. https://doi.org/10.1002/esp.3728

Tanasić, N., \& Hajdin, R. (2018). Management of bridges with shallow foundations exposed to local scour. Structure and Infrastructure Engineering, 14(4), 468-476. https://doi.org/10.1080/15732479.2017.1406960

Topczewski, Ł., Cieśla, J., Mikołajewski, P., Adamski, P., \& Markowski, Z. (2016). Monitoring of Scour Around Bridge Piers and Abutments. Transportation Research Procedia, 14, 3963-3971. https://doi.org/10.1016/j.trpro.2016.05.493

Turkish Earthquake Code (TEC) (2007). Specifications for buildings to be built in seismic areas. Ministry of Public Works and Settlement, Ankara (in Turkish).

Wang, S. T., \& Reese, L. C. (1993). COM624P: laterally loaded pile analysis program for the microcomputer, Version 2.0. US Department of Transportation, Federal Highway Administration, Office of Technology Applications.

Zheng, S., Xu, Y. J., Cheng, H., Wang, B., \& Lu, X. (2018). Assessment of bridge scour in the lower, middle, and upper Yangtze River estuary with riverbed sonar profiling techniques. Environmental monitoring and assessment, 190(1), 15. https://doi.org/10.1007/s10661-017-6393-5 